\title{
Pattern of Plant Community Distribution along the Elevational Gradient and Anthropogenic Disturbance in Gole Forest, Ethiopia
}

\author{
Mesfin Belete Hailemariam (iD) and Tamru Demsis Temam \\ Department of Biology, Wolkite University, Wolkite, Ethiopia \\ Correspondence should be addressed to Mesfin Belete Hailemariam; msbd2006@gmail.com
}

Received 28 December 2019; Revised 7 November 2020; Accepted 20 November 2020; Published 4 December 2020

Academic Editor: Nathaniel Newlands

Copyright (c) 2020 Mesfin Belete Hailemariam and Tamru Demsis Temam. This is an open access article distributed under the Creative Commons Attribution License, which permits unrestricted use, distribution, and reproduction in any medium, provided the original work is properly cited.

\begin{abstract}
Vegetation-environment relationships are usually studied along elevational gradient. The patterns of plant community distribution in Gole forest, Ethiopia, were studied along elevational gradient and disturbances. Disturbances were recorded following the elevational gradient. For vegetation data collection, 62 sample plots of size $20 \times 20 \mathrm{~m}$ were established along an elevational gradient (2728-3480 m.a.s.l). Data on species composition and environmental variables were measured and recorded in each plot. The elevation of each sample plot was measured using Garmin GPS. Anthropogenic disturbances in each plot were estimated using the following scales: $0=$ no disturbance, $1=$ slightly disturbed, $2=$ moderately disturbed, and $3=$ highly disturbed. $R$ statistical package was used for cluster and ordination analysis. Boxplots and analysis of variance were used to assess the relationships between plant communities and environmental variables. Sorensen's similarity coefficient was used to detect similarities and dissimilarities among communities. A total of 114 plant species belonging to 57 families and 94 genera were identified. Five plant community types were identified using agglomerative hierarchical cluster analysis. Every plant community had differences in composition and environmental variables. The variation in plant community distributions was significantly related to elevation and disturbance. Plant community distribution was negatively correlated with elevation $(P<0.05)$ and also with disturbance $(P<0.05)$. Sorensen's similarity index showed that there was a difference in the distribution of plant species composition among the communities. The difference in plant community distribution of Gole forest was significantly related to elevation. Disturbances also have a considerable influence on the plant communities and mitigation of disturbance should be the main measure that needs to be taken into account in conservation planning in the study area.
\end{abstract}

\section{Introduction}

Vegetation-environment relationships are usually studied along gradients. The concept of environmental gradients has been a cornerstone in the development of ecological theory [1]. Spatial and temporal patterns of vegetation change are influenced by a multitude of factors, including physical environment, land use history, prior disturbance, and initial vegetation composition [2]. Species-environment relationships are the most important data needed to understand vegetation patterns on forest landscapes [3-5]. Plant species sharing similar environmental affinities occupy similar sites across the landscape [6]. Thus, the variation in plant communities and species diversity is linked to environmental gradients [7].
Elevation is one of the decisive factors shaping the spatial patterns of vegetation and species diversity. There is a significant relationship between community structure, composition, and species diversity with elevation gradient and other environmental variables $[2,8]$. Different species of plants require different factors in order to survive $[5,9]$. Mountain ecosystems around the globe are known for their high biological diversity and usually have distinct biological communities (i.e., plant community) and high level of endemism due to their topography [7].

The vegetation types of Ethiopia are highly diverse, ranging from afro-alpine to desert [10]. This is due to a great geographical diversity with high and rugged mountains, flattopped plateaus, deep gorges, river valleys, and plains [11], which ranges from $116 \mathrm{~m}$ below sea level at Dallol 
Depression (Afar) to the highest mountain, Ras Dashen (Gondar), 4,620 meters above sea level [10, 12]. In Ethiopia, elevation plays a major role in plant species diversity and floristic formations [10]. As elsewhere in the tropics, anthropogenic factors and an extreme climate have severely influenced the abiotic and biotic components of forest ecosystems [13].

The forest types and plant species distribution within the Eastern Afromontane biodiversity hotspot are relatively well known for the Eastern Arc Mountains in Kenya and Tanzania, but the montane forests of Ethiopia have so far been described mainly on the basis of herbarium specimens or qualitative field observations; only very few quantitative surveys exist [13]. The investigations of vegetation composition, distribution patterns, and other factors that account for plant distribution patterns are an important input for conservation planning. However, studies have not been made before on the type of plant communities and the factors governing the distribution of plant communities in Gole forest, Ethiopia. Therefore, the present study (1) identifies the type of plant community in Gole forest, (2) relates the distribution pattern of plant communities with an elevational gradient, (3) describes the impact of disturbance on plant community distribution, and (4) explores the impact of environmental (elevation) and disturbance variables on species richness.

\section{Materials and Methods}

2.1. Description of the Study Area. The study was conducted in Gole natural forest which is found in Dodola woreda, West Arsi Zone of Oromia Regional State, Ethiopia. It is located in the southeast part of the country, $320 \mathrm{~km}$ away from the capital city Addis Ababa. The study area is found between latitude $6^{\circ} 51^{\prime}$ and $6^{\circ} 53^{\prime} \mathrm{N}$ and longitude between $39^{\circ} 11^{\prime}$ and $39^{\circ} 12^{\prime} \mathrm{E}$, east of Dodola town in Deneba kebele. The area is characterized by undulating land features, including mountains, flat lands holding pastures and agricultural fields, and valleys having pasture fields. The altitudinal range of the study area is between 2728 and 3480 m.a.s.l (Figure 1). The study area is characterized by bimodal rainfall distribution with the main rainy season between June to September and the short rainy season during the months of March and April. The average annual rainfall is $855 \mathrm{~mm}$ and the annual average temperature is $17^{\circ} \mathrm{C}[14]$.

\subsection{Methods.}

2.3. Sampling Technique. Data on species composition and environmental variables were measured and recorded in each plot. Along with elevation gradients of 2728-3480 m.a.s.1, 62 sample plots having a design of size $20 \times 20 \mathrm{~m}$ were established at a distance of $100 \mathrm{~m}$ between each plot along six transect lines, which was laid side by side starting from the top of the mountain. Vegetation data collection and sampling techniques were as stated in the work of Boehmer and Temam [14] that focus on species composition, structure, and regeneration status of Gole forest (http://www.alliedacademies.
org/journal-agricultural-science-botany/ISSN: 2591-7897). To determine the environmental factors that govern the distribution of plant community types, elevation and geographical coordinates were measured using Garmin GPS at the center of each plot. The types of disturbances were recorded from each plot. The intensity of anthropogenic disturbance in each plot was estimated as a sum (cumulative effect) of the following parameters: Grazing/browsing intensity which was estimated based on the following scales: $0=$ no disturbance; $1=$ slight; $2=$ moderate; $3=$ heavily and $4=$ destructive $[15,16]$, the number of trees and shrubs cut, the number of foot trails, and the number of seedlings trampled. Cover-abundance values were estimated using the modified Braun Blanquet scales [17].

2.4. Data Analysis. Classification and ordination methods were used to describe vegetation types and to examine the relationship between vegetation types and environmental variables. The ordination method expresses the relationships between samples, species, and environmental variables. The classification technique identified the discontinuities in the vegetation and delimited the stands into clusters having similar vegetation composition. This was supported by the significant contrasts found between clusters, as shown by Tukey's family error rate test. Vegetation data were analyzed using agglomerative hierarchical cluster analysis with similarity ratio as a resemblance index and Ward's linkage method to identify vegetation assemblages in plant community types. Similarity ratio is one of the similarity indices which measure the similarity or dissimilarity between vegetation samples or quadrats/ plots. The choice of a distance measure is an ecological, not a statistical decision. Ward's linkage method uses analysis of a variance approach to evaluate the distances between clusters. This method attempts to eliminate the differences in total abundance among sample units. In addition, Ward's method minimizes the total within-group mean of squares or residual sum of squares [18].

$\mathrm{R}$ statistical package [19] was used for cluster and ordination analysis. Indicator species analysis was performed to find indicator species characterizing the communities. Indicator species analysis was performed in $\mathrm{R}$ using package labdsv [20]. Boxplots and one-way analysis of variance (ANOVA) were used to assess the relationships between plant communities and elevation and plant communities with disturbance intensity. A square root (sqrt) is used to normalize the data, stabilize the variance, and give more power. Tukey's test was performed to detect significant differences among the different means of the environmental parameters of each community type. Sorenson's index of similarity (Ss) was computed to assess the floristic similarity between communities.

\section{Results and Discussion}

3.1. Floristic Composition. A total of 114 species of vascular plants, belonging to 94 genera and 57 families were recorded from 62 plots laid in the forest (Table 1). The families with the highest number of species were Asteraceae, represented by 21 species, followed by Acanthaceae (5 species), 


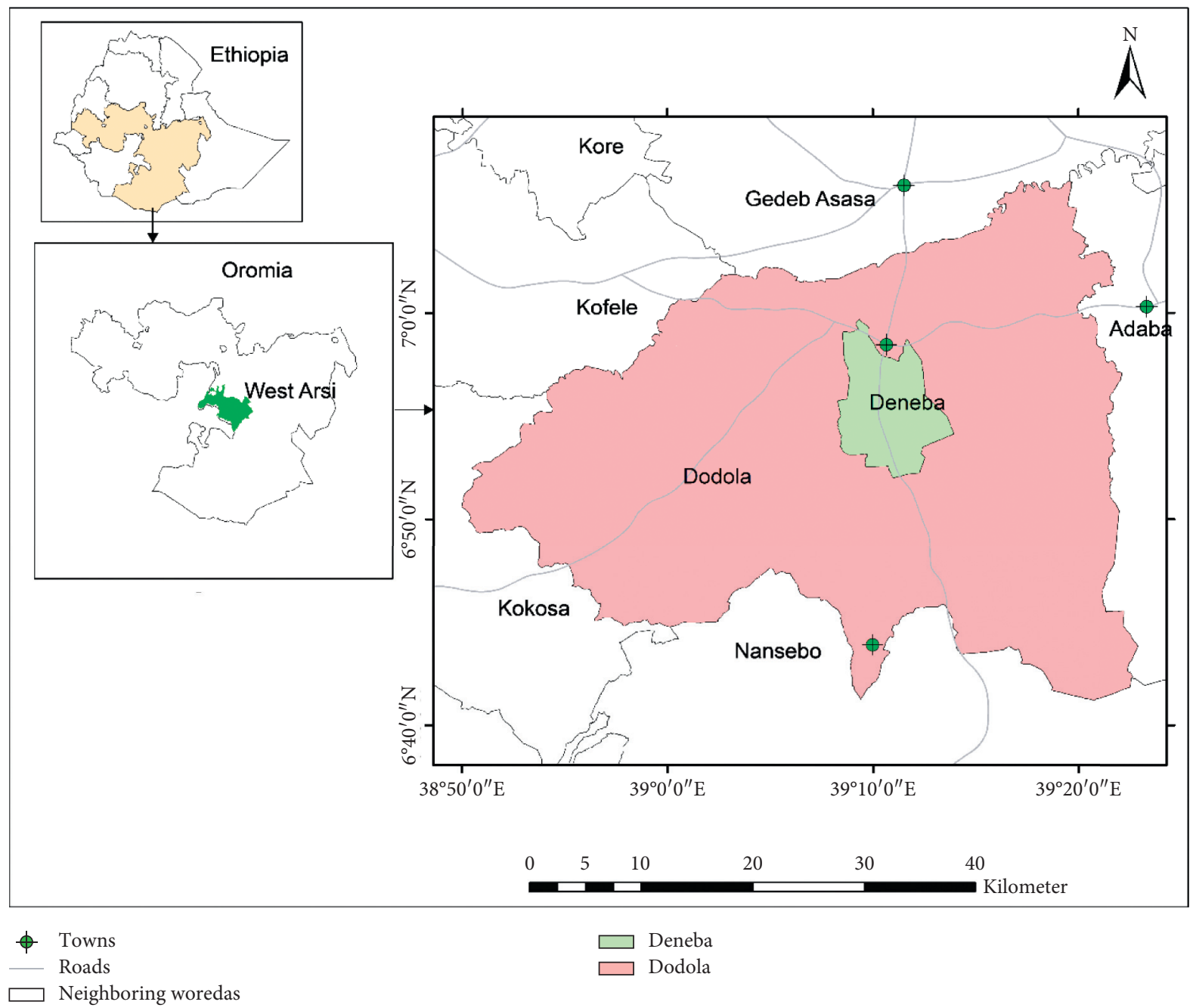

Figure 1: Location map of the study area (Gole forest), Ethiopia.

Lamiaceae (5 species) and Rosaceae (5 species), Cyperaceae (4 species), and Poaceae (4 species). The remaining families were represented by three to one species each [14]. The species were composed of 25 trees, 27 shrubs, 43 herb, 11 climber, 6 grass, and 2 fern species. 17 species have been recorded to be endemic to Ethiopia. From the endemic species, herbs constitute $58.82 \%$, shrubs $35.29 \%$, and climbers $5.88 \%$. The presence of these endemic species in the forest shows the importance of the conservation process of this forest.

3.2. Vegetation Community Classification. Five plant community types (clusters) were determined on the basis of plots grouping by similarity. The five plant communities were designated as $\mathrm{C} 1, \mathrm{C} 2, \mathrm{C} 3, \mathrm{C} 4$, and $\mathrm{C} 5$, as shown in the dendrogram (Figure 2). The plots that are grouped into one cluster are more similar in species composition and closely related in elevation than the other group of plots that are placed in the other clusters. The community types varied in size, ranging from $4-17$ plots and $27-78$ species. The highest plot numbers and species were found in community type 4 (C4), whereas the least in community $1(\mathrm{C} 1)$.
Each of these plant communities is characterized by a group of plants that show a strong preferential distribution in the respective community. Table 2 presents the list of species with significant indicator values in each community. The species with the highest indicator values were used for naming the communities. Hence, the plant communities identified in the study area were: Erica arborea-Conyza spinosa community type, which is composed of 4 quadrats and 27 species, Hypericum revolutum community type composed of 16 quadrats and 50 species, Hagenia abyssinicaMyrsine melanophloeos-Juniperus procera community type composed of 11 quadrats and 40 species, Nuxia congistaMyrsine africana-Osyris quadripartita community type composed of 17 quadrats and 78 species and Podocarpus falcatus-Mytenus arbutifolia-Dovyalis abyssinica community type of 14 quadrats and 75 species were identified in the study area. Each of the communities has the characteristic/ indicator species that are presented in Table 2. The indicator species show strong preferential distributions in the communities identified by cluster analysis. The indicator values of the species were considered significant if the respective probability values were less than 0.05 [21]. 
TABLE 1: List of plants species recorded from the study area (Gole forest).

\begin{tabular}{|c|c|c|c|c|}
\hline No. & Scientific name & Local name & Family & Habit \\
\hline 1 & Acanthus sennii Chiov. & Sookooru & Acanthaceae & Sh \\
\hline 2 & Achyranthes aspera (L.) & Gerbebo & Amaranthaceae & $\mathrm{H}$ \\
\hline 3 & Agave sisalana Perr.ex Eng & qaacaa & Agavaceae & $\mathrm{H}$ \\
\hline 4 & Allophyllus abyssinica (Hochest) Radel & & Spindaceae & $\mathrm{T}$ \\
\hline 5 & Alepidea longifolia E.Mey & Logaa & Apiaceae & $\mathrm{H}$ \\
\hline 6 & Arisaema schimperianum Schott & Budhee & Araceae & $\mathrm{H}$ \\
\hline 7 & Arundinaria alpina K.Schum & & Poaceae & T out \\
\hline 8 & Aspargus africanus Lam. & Seritii & Aspargaceae & $\mathrm{C}$ \\
\hline 9 & Berula erecta (Hudson) Coville & Gonde & Apiaceae & $\mathrm{H}$ \\
\hline 10 & Bidens pachyloma (Olive Heirn) & Qinxaa & Asteraceae & $\mathrm{H}$ \\
\hline 11 & Buddleja polystachya Fresen & Bulchana & Scrophulariaceae & $\mathrm{T}$ \\
\hline 12 & Bursama abyssinica Fresen. & & Melianthaceae & Sh \\
\hline 13 & Calamagrostis epigejos (L.) Roth & Maxaa & Poaceae & G \\
\hline 14 & Carduus camaecephalus (Vatke) Oliv.\& Heirn & Canaa babaxee & Asteraceae & $\mathrm{H}$ \\
\hline 15 & Carduus nyassanus R.E Fries & Qoree bosoonaa & Asteraceae & $\mathrm{H}$ \\
\hline 16 & Caucanthus auriculatus Forssk & Dikii & Malpighiaceae & $\mathrm{C}$ \\
\hline 17 & Clematis hirsuta Perr.\& Guill. & Fitii & Ranunculaceae & $\mathrm{C}$ \\
\hline 18 & Conyza spinosa Sch.Bip.ex A.Rich & Hamaresaa & Asteraceae & Sh \\
\hline 19 & Crepis rueppelli Sch.Bip & & Asteraceae & $\mathrm{H}$ \\
\hline 20 & Crinum abyssinicum Hochst.ex A.Rich & Lacee & Amaryllidaceae & $\mathrm{H}$ \\
\hline 21 & Cyanotis berbata D. Don & Daluma & Commelinaceae & $\mathrm{H}$ \\
\hline 22 & Cyanoglossum amplifolium Hochst & Qorich michi & Boraginaceae & $\mathrm{H}$ \\
\hline 23 & Cyanoglossum geometricum (Back\&Write) Edward & Maxxanee & Boraginaceae & $\mathrm{H}$ \\
\hline 24 & Cyphostemma adenocaule (Steud.ex A.Rich) & Sinoolee & Vitaceae & $\mathrm{C}$ \\
\hline 25 & Cyprus fischerianus A.Rich & Qunii & Cyperaceae & G \\
\hline 26 & Cyprus dichroostachyus A.Rich & Arbegedo & Cyperaceae & G \\
\hline 27 & Cyprus rotundus $L$. & & Cyperacaea & G \\
\hline 28 & Digitaria abyssinica Hochst. ex A.Rich & Ura sar & Poaceae & G \\
\hline 29 & Discopodium pennnervum Hochst & & Solanaceae & Sh \\
\hline 30 & Dombeya torida (J.F.Gmel) P.Bamps & Danisa & Sterculiaceae & $\mathrm{T}$ \\
\hline 31 & Dovyalis abyssinica (A.Rich) Warb & & Flacourtiaceae & Sh \\
\hline 32 & Dryopteris anthamantica (Kuntze) Kuntze & & Aspidiaceae & $\mathrm{F}$ \\
\hline 33 & Dryopteris inaequalis (Schlecht) Kuntze & kumbuutaa & Aspidiaceae & $\mathrm{F}$ \\
\hline 34 & Echinops ellenbekii $D . H o f f m$ & koshoshila & Asteraceae & Sh out \\
\hline 35 & Echinops longisetus A.Rich & Qore haree & Asteraceae & $\mathrm{H}$ \\
\hline 36 & Ekebergia capensis Sparrm & Anonuu & Miliaceae & $\mathrm{T}$ \\
\hline 37 & Erica arborea $L$ & Sato & Ericaceae & $\mathrm{T}$ \\
\hline 38 & Euphorbia schimperiana Scheele & Gurii & Euphorbiacaea & $\mathrm{H}$ \\
\hline 39 & Festuca abyssinica Hochst.ex A.Rich & & Poaceae & G \\
\hline 40 & Ficus sur Forssk. & & Moraceae & $\mathrm{T}$ \\
\hline 41 & Galiniera saxifraga (Hochst) Bridson & korralaa & Rubiaceae & $\mathrm{T}$ \\
\hline 42 & Girardinia bullosa (Steudel) Wedd. & Dobi arbo & Urticaceae & $\mathrm{H}$ \\
\hline 43 & Gnaphalium rubriflorum Hilliard & badubera & Asteraceae & $\mathrm{H}$ \\
\hline 44 & Gomphocarpus integer (NE.Br) & Halmalaa & Asclepiadaceae & $\mathrm{H}$ \\
\hline 45 & Guizotia scabra (Vis) Chiov. & Hada & Asteraceae & $\mathrm{H}$ \\
\hline 46 & Hagenia abyssinica (Bruce) J.F.Gmel & & Rosaceae & $\mathrm{T}$ \\
\hline 47 & Haplocarpha schimperi Sch.Bip & Canaa & Asteraceae & $\mathrm{H}$ \\
\hline 48 & Helichrysum foetidum Moench & & Asteraceae & $\mathrm{H}$ \\
\hline 49 & Helichrysum formosissmum (Sch.Bip) A.Rich & Handadhama & Asteraceae & $\mathrm{H}$ \\
\hline 50 & Helichrysum splendidum (Thumb) Less. & Xuqa & Asteraceae & $\mathrm{H}$ \\
\hline 51 & Hypericum peplidifolium A.Rich & Geremba merga & Hypericaceae & $\mathrm{H}$ \\
\hline 52 & Hypericum revolutum Vohl & & Hypericaceae & $\mathrm{T}$ \\
\hline 53 & Hypoestes triflora (Forssk) Roem. \& Schult & Dobi laaleesaa & Acanthaceae & $\mathrm{H}$ \\
\hline 54 & Ilex mitis (L.) Radik & Amshiqa & Aquifoliaceae & $\mathrm{T}$ \\
\hline 55 & Inula conifertiflora A.Rich & Haxawii & Asteraceae & Sh \\
\hline 56 & Ipomoea involucrata Beauv. & Hadhname & Convolvulaceae & $\mathrm{C}$ \\
\hline 57 & Isoglossa somalensis Lindau & Cafaraa & Acanthaceae & Sh \\
\hline 58 & Isolepis setacea (L.) R.Bir & Gemegna & Cyperaceae & $\mathrm{H}$ \\
\hline 59 & Jasminum abyssinicum Hochst ex. Endi & Haroolaa & Oleaceae & $\mathrm{C}$ \\
\hline 60 & Juniperus procera Hochst ex Endl & & Cuprussaceae & $\mathrm{T}$ \\
\hline
\end{tabular}


TABle 1: Continued.

\begin{tabular}{|c|c|c|c|c|}
\hline No. & Scientific name & Local name & Family & Habit \\
\hline 61 & Kalanchoe petitiana A.Rich & & Crassulaceae & $\mathrm{H}$ \\
\hline 62 & Kniphofia foliosa Hochst & Lelaa & Asphodelaceeae & $\mathrm{H}$ \\
\hline 63 & Lantana trifolia $L$ & Kese & Verbnaceae & Sh \\
\hline 64 & Maesa lanceolata Forssk. & & Myrisinaceae & $\mathrm{T}$ \\
\hline 65 & Mikaniopsis clematoides (A.Rich) M.Radh & Qarqoraa & Asteraceae & $\mathrm{C}$ \\
\hline 66 & Minulopsis solmisii Schwan & Herayee & Acanthaceae & $\mathrm{H}$ \\
\hline 67 & Myosotis abyssinica Bois \& Revt & Qarcabaa & Boraginaceae & $\mathrm{H}$ \\
\hline 68 & Myrica salcifolia A.Rich & Xonaa/shinet & Myricaceae & T out \\
\hline 69 & Myrsine africana $L$. & & Myrisinaceae & $\mathrm{Sh}$ \\
\hline 70 & Myrsine melanophloeos (L.) R.Br & & Myrisinaceae & $\mathrm{T}$ \\
\hline 71 & Mytenus addat (Loes) Sebsebe & Qarxame/Atat & Celasteraceae & Sh \\
\hline 72 & Mytenus arbutifolia R. Wilczek & & Celastraceae & $\mathrm{T}$ \\
\hline 73 & Nuxia cogista R.Br.ex.Fresen & Bixanaa & Stilbaceae & $\mathrm{T}$ \\
\hline 74 & Ocimum lamiifolium Hochst ex Benth. & Damakese & Lamiaceae & Sh out \\
\hline 75 & Ocimum urticifolium Roth. & Hubunee & Lamiaceae & Sh \\
\hline 76 & Olea europea Sub sp.cuspidata (Well ex.G.Don) c.f & & Oleaceae & $\mathrm{T}$ \\
\hline 77 & Olea hochstetteri Back. & Ejersa dhalaa & Oleaceae & T out \\
\hline 78 & Olinia rachetiana A.Jussieu & Gunaa/sole & Oliniaceae & $\mathrm{T}$ \\
\hline 79 & Osyris quadripartita Decn & Kaaro/qerest & Santalaceae & Sh \\
\hline 80 & Periploca linearifolia Quart-Dill. \& A.Rich & anannoo & Asclepiadaceae & $\mathrm{C}$ \\
\hline 81 & Phytolaca dodecandra $L^{\prime}$ Her't & & Phytolacaceae & Sh \\
\hline 82 & Pittosporum abyssinicum Dilile & Araa & Pittosporaceae & $\mathrm{T}$ \\
\hline 83 & Plantago lanceolata $L$. & Qarxobii & Plantaginaceae & $\mathrm{H}$ \\
\hline 84 & Plectranthus punctatus L'Herit & Gogoro & Lamiaceae & $\mathrm{H}$ \\
\hline 85 & Podocarpus falcatus (Thunb) Mirb & & Podocarpaceae & $\mathrm{T}$ \\
\hline 86 & Prunus africana (Hook. f) Spreng & Suke & Rosaceae & $\mathrm{T}$ \\
\hline 87 & Pterolobium stellantum (Forssk.) Brenan & Sokooru gaalee & Acanthaceae & $\mathrm{C}$ \\
\hline 88 & Rhamnus staddo A.Rich & Qadidaa & Rhamnaceae & $\mathrm{T} / \mathrm{sh}$ \\
\hline 89 & Rhamnus prinoids L'Herit & & Rhamnaceae & $\mathrm{Sh}$ \\
\hline 90 & Rhus vulgaris Mikle & Xaaxeesaa & Anacsrdiaceae & Sh \\
\hline 91 & Rosa abyssinica Lindley & & Rosaceae & Sh \\
\hline 92 & Rubus apetalus Poir. & Gora/Enjori & Rosaceae & Sh \\
\hline 93 & Rubus steudneri Schweinf. & Gora hagena & Rosaceae & Sh \\
\hline 94 & Rumex nepalensis Spreng & Shabee & Polygonaceae & $\mathrm{H}$ \\
\hline 95 & Satureja biflora (Hom. ex Don) Brif. & Xoshmaxaa & Lamiaceae & $\mathrm{H}$ \\
\hline 96 & Scadoxus multiflorus (Martyn) Raf. & Arfaasaa & Amaryllidacaea & $\mathrm{H}$ \\
\hline 97 & Schefflera volkensii (Engl.) Horms & Ansha & Araliaceae & $\mathrm{T}$ \\
\hline 98 & Senecio freseni Sch. Bip ex oliv. & Agedenaa & Asteraceae & $\mathrm{H}$ \\
\hline 99 & Senecio myriocephalum Sch. Bip.ex A.Rich & & Asteraceae & $\mathrm{H}$ \\
\hline 100 & Sida schimperiana Hochst.ex A.Rich & Enchakire & Malvaceae & Sh \\
\hline 101 & Solanecio gigas (Vitke)C.jeffrey & Yeshikoko gomen & Asteraceae & Sh \\
\hline 102 & Solanum giganteum Jacq. & & Solanaceae & Sh \\
\hline 103 & Solanum indicum $L . f$ & Hidi oromo & Solanaceae & Sh \\
\hline 104 & Stellaria sennii Chiov. & Duqushaa & Cryophyllaceae & $\mathrm{H}$ \\
\hline 105 & Stephania abyssinica (DillonઐA.Rich). Walp & kalaalaa & Minispermaceae & $\mathrm{C}$ \\
\hline 106 & Thymus schimperi Ronn. & Tosign & Lamiaceae & $\mathrm{H}$ \\
\hline 107 & Tragia brevipes $P a x$ & Laaleesaa & Euphorbiaceae & $\mathrm{H}$ \\
\hline 108 & Trifolium calocephalum Fresen & Gosa siidisaa & Fabaceae & $\mathrm{H}$ \\
\hline 109 & Trifolium quartinianum A.Rich & Sidiisaa & Fabaceae & $\mathrm{H}$ \\
\hline 110 & Urera hypselodendron (A.Rich) Wedd. & Haalilaa & Urticaceae & $\mathrm{C}$ \\
\hline 111 & Urtica simensis Steud. & & Urticaceae & $\mathrm{H}$ \\
\hline 112 & Vernonia adoensis Sch.Bip ex Walp & Ye feres zeng & Asteraceae & Sh out \\
\hline 113 & Vernonia amygdalina Del. in cail. & Ebicha & Asteraceae & Sh out \\
\hline 114 & Vernonia myriantha Hook.f & Rejii & Asteraceae & Sh \\
\hline
\end{tabular}

$\mathrm{C}=$ Climbers, $\mathrm{Sh}=$ Shrubs, $\mathrm{T}=$ Trees, $\mathrm{H}=$ Herbs, $\mathrm{F}=$ Ferns and out $=$ found out of quadrat. 


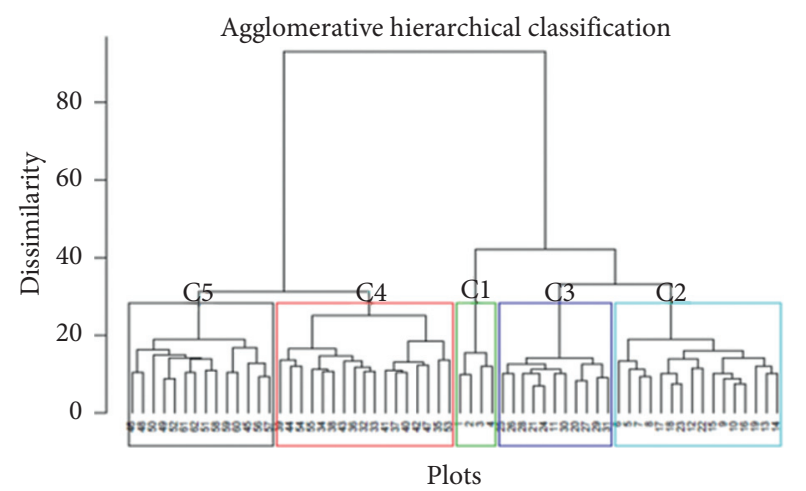

FIgURE 2: Dendrogram of the vegetation data obtained from hierarchical cluster analysis.

3.3. Community-Environment Relationship. Environmental factors such as elevation, disturbance, etc., affect species distribution, diversity, and richness. The classification technique identifies the discontinuity in vegetation, and the major discrimination in vegetation distribution among the plant communities in this study was most strongly controlled by altitude and disturbances.

Elevation has a remarkable impact on Gole forest plant community formation. The Boxplots of the elevation/altitude of each plant community show that there is considerable variation in elevation among the plant communities in the study area (Figure 3).

The classification identifies the discontinuity in the vegetation type of the communities, and this is supported by the significant contrasts found between communities, as shown by Tukey's test. The comparison of plant communities with each other based on elevation shows that plant community one was significantly different from community two, three, four, and five, and vice versa (Figure 3). Community type one (Erica arborea-Conyza spinossa community) was recorded at the highest elevation (3388-3480) compared to community five (Podocarpus falcatus-Mytenus arbutifolia-Dovyalis abyssinica community) which is found in the lowest elevation (2728-2863 $\mathrm{m}$ a. s.l.) and the other community two (Hypericum revolutum community), three (Hagenia abyssinica-Myrsine melanophloeos-Juniperus procera community), and four (Nuxia congista-Myrsine africana-Osyris quadripartita community) are found between this two community.

The significance of variation in elevation of the plant communities was assessed using ANOVA. The analysis of variance shows that the distribution of the five plant communities was significantly different across elevation (mean square $=168.39, D . f=4, F<2.2 e-16^{* * *}$, correlation is significant at $P<0.05)$. This implies that elevation has a considerable impact on the distribution pattern of plant communities.

Topographic variables such as elevation indicate the availability of resources required by plants and influence environmental conditions of a particular site, thus causing a prominent variation in species composition. Elevation determines the distribution pattern of vegetation or
TABLE 2: Indicator species in each community with significant indicator values (\%).

\begin{tabular}{lccc}
\hline Species & Community & $\begin{array}{c}\text { Indicator value } \\
(\%)\end{array}$ & $\begin{array}{c}P \\
\text { value }\end{array}$ \\
\hline Erica arborea & 1 & 65.91 & 0.001 \\
Conyza spinosa & 1 & 46.85 & 0.002 \\
Hypericum revolutum & 2 & 46.36 & 0.003 \\
Hagenia abyssnica & 3 & 43.59 & 0.009 \\
Myrsine melanophloeos & 3 & 34.49 & 0.002 \\
Juniperus procera & 3 & 31.16 & 0.001 \\
Myrsine africana & 4 & 72.37 & 0.001 \\
Osyris qudripartita & 4 & 40.64 & 0.007 \\
Nuxia congista & 4 & 38.96 & 0.007 \\
Podocarpus falcatus & 5 & 76.76 & 0.001 \\
Mytenus arbutifolia & 5 & 59.95 & 0.001 \\
Dovyalis abyssinica & 5 & 53.97 & 0.002 \\
\hline
\end{tabular}

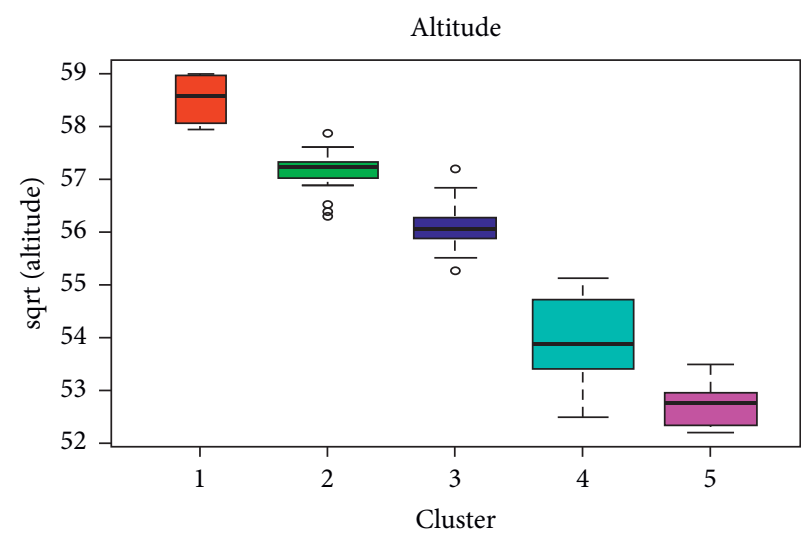

FIgURE 3: Boxplots of the association of plant community types with altitude/elevation.

communities in the site and hence is considered as a major parameter in ecological specialization [22-24]. The elevation species distributions are due to factors which change in conjunction with an elevation that include air pressure, temperature, and precipitation that in turn determine the type of vegetation [25].

\subsection{Relation between Disturbance and Plant Communities.} There was a considerable variation in disturbance between the plant communities of the study area (Figure 4).

The result of ANOVA indicates that there is a significant difference in disturbance level among plant Communities (mean square $=2.9228, D . f=4, F<0.02871^{*}$ Correlation is significant at $P<0.05$ ).

In community one (Erica arborea community type), which is found at the upper elevation, there is less disturbance as compared to Community five (Podocarpus falcatusMytenus arbutifolia-Dovyalis abyssinica Community type), which is found at the lowest elevation. In communities two and three, there are relatively high levels of disturbance than communities one and four but less level of disturbance than community five. Community three has a high level of disturbance than community four but less level of disturbance 


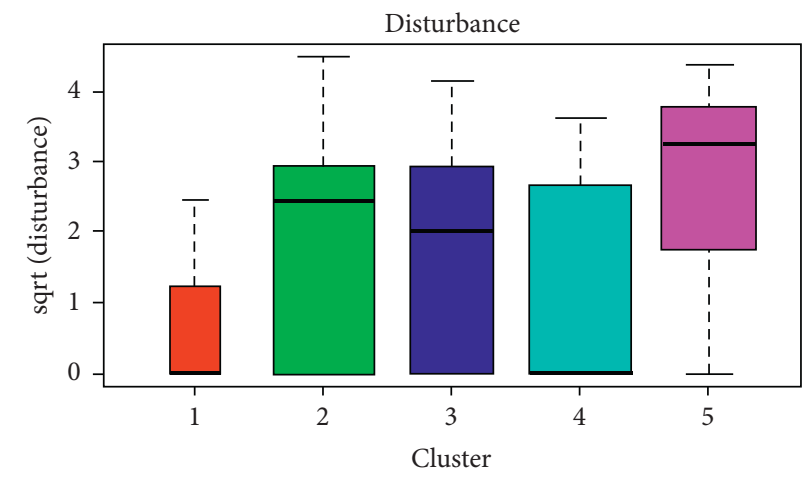

FIGURE 4: Boxplot showing the association of disturbance with plant community types.

TABLE 3: Species richness among the five plant communities in Gole forest.

\begin{tabular}{lcc}
\hline Communities & No. of species & Altitudinal range \\
\hline Community_1 & 27 & $3388-3480$ \\
Community_2 & 50 & $3173-3350$ \\
Community_3 & 40 & $3050-3275$ \\
Community_4 & 78 & $2758-3040$ \\
Community_5 & 75 & $2728-2863$ \\
\hline
\end{tabular}

than community five, while community four has less level of disturbance than community five. A high level of disturbances was recorded in community five. This can be attached to the high human interference because of the proximity of the community to human settlement and high overgrazing and overbrowsing by domestic stocks.

Intermediate level of disturbance was recorded in communities two and three. In these communities, woody species were cut down for charcoal and timber production. The low level of disturbance was in communities one and four; community one was found far from human settlement and community four was mainly dominated by shrubs which cannot grow to a high height and DBH class which is less valuable for human use. It is dominated by Osyris quadripartita and Myrsine africana. This species is a less valuable woody species for commercial purposes and also resistant to wild animals and livestock grazing.

Disturbance governs community patterns by altering the environment and resource distributions, creating enabling conditions for the establishment of new species or minimizing populations of established species [26]. Disturbance also alters the stability and diversity of ecosystems as it reduces invasion resistance while eliminating the buffering effect of high diversity [27].

As indicated by Boehmer and Temam [14], the distribution of plant species among the communities in the study area shows the highest similarity between communities four and five (59\%), three and four (44\%), and two and three (41\%) and the lowest similarity was observed between communities one and five (11\%). This is due to the existence of quadrats adjacent to each other and similarity in altitudes. This shows that communities having nearly similar altitudes have more species in common than communities occupying different altitudes. As Oksanen [28] states that, if two sites have similar vegetation, they have a similar environment and if two sites have different vegetation, they have a different environment.

3.5. Species Richness of the Communities in relation to Environmental Variables. The species richness of the plant communities was high in community four (78), followed by community five (75), two (50), and three (40), while community one (27) was the least in species richness (Table 3).

The highest species richness in community $\mathbf{4}$ is due to intermediate altitude, fewer disturbances, and covered with less valuable woody species (shrubs) for commercial purposes and also resistance to wild animal and livestock grazing. In community $\mathbf{5}$, the lower altitude makes moderate conditions for rapid resource acquisition, which is favorable for most plant growth. However, in communities 3 and 2, the species richness decreases due to disturbance and increasing altitude. While in community $\mathbf{1}$, species richness was reduced due to increasing altitude leading to ecophysiological constraints. These could be the possible reasons for the declining of species richness and diversity with increasing altitude [29].

\section{Conclusion}

The present study describes the distribution of plant community types along an altitudinal gradient and disturbances in Gole forest. Understanding the environmental factors that govern plant community distribution is important in planning and implementing plant conservation and management strategies. Five plant community types have been 
distinguished and related to measured environmental variables. The main variation in the distribution of plant communities in the Gole forest was due to the altitudinal gradient and disturbances. There are differences in species richness among the plant communities. Finally, the distribution of plant communities and species richness was affected by elevation and disturbance. Therefore, considering the environmental factors is important for implementing plant conservation and management strategies.

\section{Data Availability}

The raw data used to support the findings of this study have been deposited in the Dryad repository https://doi.org/10. 5061/dryad.zcrjdfn74.

\section{Conflicts of Interest}

The authors declare that there are no conflicts of interest regarding the publication of this paper.

\section{Supplementary Materials}

The MSC Data file contains the raw data which are used to support the findings of this study. (Supplementary Materials)

\section{References}

[1] J. A. Zavala-Hurtado, P. L. Valverde, A. Díaz-Solís, F. Vitel, and E. Portilla, "Vegetation-environment relationships based on a life-forms classification in a semiarid region of Tropical Mexico," Revista de Biología Tropical, vol. 44, no. 2, pp. 581-590, 1996.

[2] S. C. Goslee, W. A. Niering, D. Urban, and N. L. Christensen, "Influence of environment, history and vegetative interactions on stand dynamics in a Connecticut forest1," The Journal of the Torrey Botanical Society, vol. 132, no. 3, pp. 471-482, 2005.

[3] C. T. Wang, R. Long, J. Wang, L. M. Ding, and M. P. Wang, "Effects of altitude on plant-species diversity and productivity in an alpine meadow, Qinghai-Tibetan plateau," Australian Journal of Botany, vol. 55, pp. 110-117, 2007.

[4] S. Arekhi, M. Heydari, and H. Pourbabaei, "Vegetation-environmental relationships and ecological species groups of the Ilam Oak Forest Landscape, Iran," Caspian Journal of Environmental Sciences, vol. 8, no. 2, pp. 115-125, 2010.

[5] E. Kouhgardi, G. H. Amiri, K. Sagheb-Talebi, and M. Akbarzadeh, "The effects of soil characteristics and physiographic factors on the establishment and distribution of plant species in mountain forests (Case study: asalouyeh, South of Iran)," International Journal of Biodiversity and Conservation, vol. 3, no. 9, pp. 456-466, 2011.

[6] P. C. Goebel, B. J. Palik, L. K. Kirkman, M. B. Drew, L. West, and D. C. Pederson, "Forest ecosystems of a Lower Gulf Coastal Plain landscape: multifactor classification and analysis," Journal of the Torrey Botanical Society, vol. 128, no. 1, pp. 47-75, 2001.

[7] S. Gairola, R. Rawal, and N. P. Todaria, "Forest vegetation patterns along an altitudinal gradient in sub-alpine zone of west Himalaya, India," African Journal of Plant Science, vol. 2, no. 6, pp. 42-48, 2008.

[8] D. Meng, J.-T. Zhang, and M. Li, "Diversity of woodland communities and plant species along an altitudinal gradient in the guancen mountains, China," The Scientific World Journal, vol. 2012, Article ID 398765, 1 page, 2012.

[9] M. Pidwirny, "Abiotic factors and the distribution of species," Fundamentals of Physical Geography, 2nd edition, 2006, http://www.physicalgeography.net/fundamentals/9e.html.

[10] I. Friis, S. Demissew, and P. van Bruegel, Atlas of the Potential Vegetation of Ethiopia, Vol. 58, The Royal Danish Academy of Science and Letters, Biologiske Skrifter, Copenhagen, Denmark, 2010.

[11] FAO, "Role of planted forests and trees outside forests," in Sustainable Forest Management in the Republic of Ethiopia, I. Thomas and M. Bekele, Eds., Forest Resources Development Service, Forest Resources Division. FAO, Rome, Italy, 2003.

[12] A. Husen, V. K. Mishra, K. Semwal, and D. Kumar, "Biodiversity status in Ethiopia and challenges," in Environmental Pollution and Biodiversity, vol. 1, pp. 31-79, Discovery Publishing House Pvt Ltd., New Delhi, India, 2012.

[13] E. Aynekulu, R. Aerts, P. Moonen et al., "Altitudinal variation and conservation priorities of vegetation along the Great Rift Valley escarpment, northern Ethiopia," Biodiversity and Conservation, vol. 21, no. 10, pp. 2691-2707, 2012.

[14] M. B. Boehmer and T. D. Temam, "The vegetation composition, structure and regeneration status of Gole natural forest, West Arsi zone, Oromia regional state, Ethiopia," Journal of Agricultural Science and Botany, vol. 2, no. 2, pp. 10-21, 2018.

[15] W. Zerihun and I. Backéus, "The shrub land vegetation in Western Shewa, Ethiopia and its possible recovery," Journal of Vegetation Science, vol. 2, pp. 173-180, 1991.

[16] Z. Tadesse, E. Kelbessa, and T. Bekele, "Floristic composition and plant community analysis of vegetation in Ilu Gelan district, West Shewa Zone of Oromia region, Central Ethiopia," Tropical Plant Research, vol. 4, no. 2, pp. 335-350, 2017.

[17] E. Bekele, Vegetation Ecology-An Overview, Blackwell Publishing Company, Hoboken, NJ, USA, 2005.

[18] B. McCune and J. B. Grace, Analysis of Ecological Communities, MjM Software Design, Gleneden Beach, OR, USA, 2002.

[19] R Development Core Team, The R Foundation for Statistical Computing. $R$ version 2.10, Vol. 1, R Development Core Team, Vienna, Austria, 2009.

[20] D. W. Roberts, Package "labdsv": Ordination and Multivariate Analysis for Ecology. Version 1.5-0, 2012, http://ecology.msu. montana.edu/labdsv/R.

[21] M. Dufrêne and P. Legendre, "Species assemblages and indicator species: the need for a flexible asymmetrical approach," Ecological Monographs, vol. 67, no. 3, pp. 345-366, 1997.

[22] A. Moody and R. K. Meentemeyer, "Environmental factors influencing spatial patterns of shrub diversity in chaparral, Santa Ynez Mountains, California," Journal of Vegetation Science, vol. 12, no. 1, pp. 41-52, 2001.

[23] M. Biru, "An ecological study of Biteyu Forest, Gurage Zone, Southern Nations Nationalities Peoples Region," M.Sc. thesis, AAU, Anand, India, 2003.

[24] X. M. Jin, Y.-K. Zhang, M. E. Schaepman, and J. G. P. W. Clevers, "Impact of Elevation and Aspect on the spatial distribution of vegetation in the Qilian mountain area with remote sensing data," in Proceedings of the the International Archives of the Photogrammetry, Remote Sensing and Spatial Information Sciences, vol. 37, Beijing, China, July 2008.

[25] J. G. Pausas and M. P. Austin, "Patterns of plant species richness in relation to different environments: an appraisal," Journal of Vegetation Science, vol. 12, no. 2, pp. 153-166, 2001. 
[26] K. J. Elliott and D. Hewitt, "Forest species diversity in upper elevation hardwood forests in the southern appalachian mountain," Castanea, vol. 62, no. 1, pp. 32-42, 1997.

[27] A. S. MacDougall, K. S. McCann, G. Gellner, and R. Turkington, "Diversity loss with persistent human disturbance increases vulnerability to ecosystem collapse," $\mathrm{Na}$ ture, vol. 494, no. 7435, pp. 86-89, 2013.

[28] J. Oksanen, Multivariate Analysis in Ecology-Lecture Notes, University of Oulu, Oulu, Finland, 2004.

[29] D. Dereje, "Floristic composition and ecological study of Bibita forest (Gura Ferda), Southwest Ethiopia," M. Sc. thesis, Addis Ababa University, Addis Ababa, Ethiopia, 2007. 